\title{
Arbuscular Micorrizal Fungi and Farm Management Practices
}

\author{
Azevedo EJC ${ }^{1 *}$, Parreira $\mathrm{AG}^{2}$, Duarte $\mathrm{NF}^{3}$, Souza $\mathrm{RF}^{1}$, Rodrigues $\mathrm{HC}^{1}$ and Pagano $\mathrm{MC}^{4}$ \\ ${ }^{1}$ Empresa de Pesquisa Agropecuária de Minas Gerais EPAMIG-URECO, Brazil \\ ${ }^{2}$ Universidade Federal de São João Del Rey, Campus CCO, Divinópolis, Brazil \\ ${ }^{3}$ Instituto Federal de Minas Gerais, Brazil \\ ${ }^{4}$ Universidade Federal de Minas Gerais, Brazil.
}

*Corresponding author: Eduardo Jose Azevedo Correa, Campo Experimental De Pitangui, Empresa de Pesquisa Agropecuária de Minas Gerais EPAMIG-URECO, Brazil.
Received Date: May 02, 2019

Published Date: May 13, 2019

\begin{abstract}
Arbuscular mycorrhizal fungi (AMF) are commonly present in most tropical land ecosystems; however, high rates of fertilization can disrupt their life cycle. The AMF occurrence in different crop systems compared to native vegetation in tropical conditions is not well understood. With the aim to analyze potentially benefic symbionts for crop production in an experimental farm, the AMF community structure along different crop cultivation was investigated. Soil subsamples were used to inoculate trap cultures using Sorghum sp. as host. The preserved unfertilized area showed a greater diversity of AMF, followed by the grassland and sugarcane. Number of AMF spores was also greater in the preserved area (47 spores per $100 \mathrm{~g}$ soil) than the numbers estimated for other sites. Nine AMF genera of Glomeromycotina (spores) and 16 AMF species were observed in the native forest. The natural richness appears to be favored when Sugarcane or grasses are planted; however, the preserved native forest showed unique characteristics. Soils under native forest stored higher amount of SOM, presented higher macro-aggregates and preserved more charcoal than the samples of permanent grassland or under maize. The maize associated AMF community diverged from grassland, as described by the principal component analysis. This study showed differences in AMF communities from cultivated plots compared to native vegetation as well as potential for inoculant formulation for economically crops.
\end{abstract}

Keywords: Arbuscular mycorrhizal fungi; Atlantic Forest; Sugarcane; Maize; Grassland

\section{Introduction}

It is known that land-use intensification affects multiple ecosystem services mainly by plant biodiversity loss [1], together with suppression of rhizospheric plant symbionts. Among plant-soil microbiota, the arbuscular mycorrhizal fungi (AMF) have common occurrence. However, some plant species do not perform symbioses with that fungi), differently that most agronomic species [2]. Nevertheless, the use of fertilizers and the type of plant-soil management can affect the occurrence and diversity of AMF species compared with preserved areas [3]. Increasingly reports on maize showed higher AMF richness under optimized N input agro-systems [4].

Moreover, chemical fungicides can also affect root colonization by AMF as well as the number of spores [5]. Fertilization regimes have impacts on maize root-associated AMF community [6]. Recent reports showed that oxisoil $\mathrm{Al}$ saturation present in Brazilian tropical soils can change the AMF richness in maize roots [7].

Soil aggregation is sensitive to changes in management practices [8], in soil compaction and in plant and edaphic animal populations [9].
The morphological spore identification can provide a more sensitive detection of changes in AMF community composition and diversity in fields than molecular methods [10], as detected in some analysis carried out under temperate climate in plots subjected to intensive agriculture and no-till treatments that showed negative effects of tillage for AMF diversity [11].

Opik et al. [12] compiled information on number of AMF taxa and showed significantly higher richness in tropical forests, followed by grasslands and cultivated areas. The AMF occurrence in different crop systems compared to native vegetation in tropical regions such as in Brazil was not well investigated. In Brazil, the Atlantic Forest biome contribute to multiple environmental functions; however, the original area was extremely reduced, resulting in immediate conservation measures. Most reports showed that conversion of Atlantic Forest into pasture changes the biological properties and dynamics of SOM [13].

The Atlantic Forest in Southeastern Brazil is found in small fragments in the Meso-region of Belo Horizonte, Minas Gerais State, 
where plant species from Atlantic Forest and Cerrado Brazilian biomes, both considered as hotspots of biodiversity [14], occur. Atlantic forest total sampled area represents simply $0.01 \%$ of the remaining biome, Minas Gerais state being one of the better studied [15]. However, most landscapes save for conservation purposes (marginal agricultural lands) can hold high species diversity providing biodiversity conservation services [16]. Thus, to improve the conservation of anthropogenic landscapes in Brazilian tropical forest is urgently needed [17].

With the aim to analyze AMF potentially benefic for crop production in experimental farms, we show in the present study, results of estimates of AMF communities' structure along one year of crop cultivation. The Experimental farm in Pitangui (an area of 460ha) includes preserved riparian areas between São João and Pará Rivers, localized in the São Francisco River basin, a protected Reserve (its vegetation is primarily Atlantic Forest), forestry, and corn/sugarcane fields. Experimental farm belongs to EPAMIG ITAC Company (Empresa de Pesquisa Agropecuária de Minas Gerais) located in the center-west region of the state of Minas Gerais and dedicated to research with regional cultivars potentially important for intensive systems of production or screening programs. Plant crops are rice, corn, beans, soybean, to name just a few.

Four different areas were studied from maize and sugarcane monocropping, grassland to environmentally protected Native Forest. Among cultivated pastures, Brachiaria grasslands (B. decum- bens and B. brizantha) are the most important agronomic species in Brazil, also used for Integrated Crop-Livestock-Forest systems [18]. The grassland for pasture (Brachiaria brizantha), the continuous maize monocropping with high input of fertilizers and pesticides, and sugarcane monoculture (Saccharum officinarum) fertilized only with compost were selected.

We hypothesized that soil grassland could contain high AMF spore numbers, macroaggregates and charcoal, but the native forest can present the highest values. Furthermore, we hypothesized that changes in land-use affect the fertility and structure of the soil matrix so that the overall. We predict monocultures to impact the AMF community in this study. Studies investigating AMF diversity in tropical native forest, grassland and crop fields are scarce, but no available studies have been targeted to the anthropogenic disturbances that drive AMF community shifts together with soil aggregation and charcoal content.

The aims of this study were: (1) to evaluate the communities of AMF in different ecosystems of land use intensity from undisturbed preserved and permanent grassland to monocultures, (2) to associate the AMF communities with soil characteristics and (3) to evaluate the effect of inoculation of soil containing arbuscular mycorrhizal propagules on plant growth, as part of a greenhouse experiment. Since we wanted to focus on the simple on farm inoculation (mixed AMF spores in soil) alone, we chose to compare different non-sterilized soils.

\section{Material and Methods}

\section{Field analysis}

Table 1: Historical characteristics of sites sampled in the experimental farm and adjacent preserved area (Atlantic forest).

\begin{tabular}{|c|c|c|c|c|c|c|c|}
\hline $\begin{array}{c}\text { Vegetation/ } \\
\text { Standing Crop }\end{array}$ & Abbreviation & $\begin{array}{c}\text { Geographical } \\
\text { Coordinates }\end{array}$ & Altitude (m) & $\begin{array}{c}\text { Estimated Age } \\
\text { of Forest/ Culti- } \\
\text { vation (year) }\end{array}$ & $\begin{array}{c}\text { Previous Crop / } \\
\text { Vegetation }\end{array}$ & $\begin{array}{c}\text { Historic of Fer- } \\
\text { tilizer Use }\end{array}$ & $\begin{array}{c}\text { Historic of Pesticide } \\
\text { Use }\end{array}$ \\
\hline Atlantic Forest & $\mathrm{NF}$ & $\begin{array}{c}19^{\circ} 42^{\prime} 49.9^{\prime \prime} \mathrm{S} \\
44^{\circ} 54^{\prime} 07.8^{\prime \prime} \mathrm{W}\end{array}$ & 637,05 & 30 & - & - & - \\
\hline Grassland & $\mathrm{G}$ & $\begin{array}{c}19^{\circ} 42^{\prime} 51.5^{\prime \prime} \mathrm{S} \\
44^{\circ} 53^{\prime} 37.0^{\prime \prime} \mathrm{W}\end{array}$ & 628,36 & $>25$ & $\mathrm{NA}$ & - & - \\
\hline Sugarcane & $\mathrm{S}$ & $\begin{array}{c}19^{\circ} 42^{\prime} 40.9^{\prime \prime} \mathrm{S} \\
44^{\circ} 53^{\prime} 40.0^{\prime \prime} \mathrm{W}\end{array}$ & 642,80 & 2 & Bush, grass & Compost & Herbicide VEPÀR \\
\hline Maize & $\mathrm{M}$ & $\begin{array}{c}19^{\circ} 42^{\prime} 48.1^{\prime \prime} \mathrm{S} \\
44^{\circ} 53^{\prime} 45.3^{\prime \prime} \mathrm{W}\end{array}$ & 632,88 & 10 & $\begin{array}{c}\text { Maize (high } \\
\text { cultivation } \\
\text { intensity) }\end{array}$ & $\begin{array}{c}\text { Mineral fertil- } \\
\text { izer (N:P:K= } \\
8: 28: 16 ; 400 K g \\
\text { ha-1); Urea } \\
(350 \text { Kg ha-1) }\end{array}$ & $\begin{array}{c}\text { LOSBAN, ROUNDUP } \\
\text { UpKlorpan 480 CE; } \\
\text { Herbicides SANSON } \\
40 \text { SC and DMA 806 } \\
\text { BR }\end{array}$ \\
\hline
\end{tabular}

NA: Not available. Grassland: chopped up once a year.

Study sites. The four sites (Table 1) selected for this study are located in the plain of the São Francisco River basin located in Brazil.

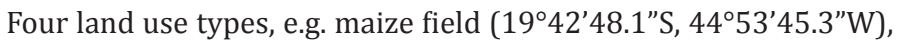
grassland (19²' $\left.51.5^{\prime \prime} \mathrm{S}, 44^{\circ} 53^{\prime} 37.0^{\prime \prime} \mathrm{W}\right)$, sugarcane $\left(19^{\circ} 42^{\prime} 40.9^{\prime \prime} \mathrm{S}\right.$

Different areas were sampled: $\left.44^{\circ} 53^{\prime} 40.0^{\prime \prime} \mathrm{W}\right)$ and Atlantic forest $\left(19^{\circ} 42^{\prime} 49.9^{\prime \prime} \mathrm{S} 44^{\circ} 54^{\prime} 07.8^{\prime \prime} \mathrm{W}.\right)$ (Representative of land use with different intensity in descending order), were selected as sampling sites.

Table 2: List of plant species identified in the permanent forest cover (AF) plots in 2014. Species are ordered by family (in alphabetical order). The characteristic biomes are also reported. Legend: ${ }^{*}=$ risk of extinction.

\begin{tabular}{|l|l|l|l|}
\hline Family & Species & Biome & AMF Status \\
\hline Arecaceae & Acrocomia aculeata (Jacq.) Lodd. & Brazilian cerrado & AM (Fonseca et al. 2015) \\
\hline Bignoniaceae & Handroanthus serratifolius & Atlantic forest & NR \\
\hline Caricaceae & Jacaratia heptaphylla & Brazilian cerrado & NR \\
\hline Caryocaraceae & Caryocar brasiliense Cambess. & Brazilian cerrado & AM (Carneiro et al. 1998) \\
\hline
\end{tabular}




\begin{tabular}{|c|c|c|c|}
\hline Cecropiaceae & Cecropia pachystachya & $\begin{array}{l}\text { Atlantic forest, Brazilian cerrado } \\
\text { (Riparian forest) }\end{array}$ & $\begin{array}{l}\text { AM (Pouyú-Rojas and Siqueira } \\
\text { 2000) }\end{array}$ \\
\hline Fabaceae & Machaerium villosum & Atlantic forest; Brazilian cerrado & NR \\
\hline Fabaceae & $\begin{array}{l}\text { Deguelia costata (Benth.) Az.- } \\
\text { Tozzi }\end{array}$ & Atlantic forest & NR \\
\hline Fabaceae (Caesalpinioideae) & Copaifera langsdorffii Desf. & Atlantic forest & $\begin{array}{l}\text { AM (Siqueira et al. 1998; Zangaro } \\
\text { et al. 2003) }\end{array}$ \\
\hline Fabaceae Caesalpinioideae & Hymenaea courbaril L. & Atlantic forest & $\begin{array}{l}\text { NM (Siqueira et al. 1998) (Pe- } \\
\text { done-Bonfim et al. 2018) }\end{array}$ \\
\hline Fabaceae (Mimosoide) & Inga vera Willd. & Atlantic forest & NR \\
\hline Fabaceae (Mimosoideae) & Stryphnodendron adstringens & Brazilian cerrado & NR \\
\hline Fabaceae (Mimosoide) & Piptadenia gonoacantha & Atlantic forest & NR \\
\hline Lauraceae & Nectandra oppositifolia & Atlantic forest & NR \\
\hline Lecythidaceae & Cariniana estrellensis ${ }^{*}$ & Atlantic forest, Brazilian cerrado & NR \\
\hline Myristicaceae & Virola sebifera Aubl. & $\begin{array}{l}\text { Tropical dry forest, Cerradão, Ri- } \\
\text { parian forest border }\end{array}$ & NR \\
\hline Monimiaceae & Siparuna guianensis Aublet. & Brazilian cerrado & NR \\
\hline Myrtaceae & $\begin{array}{l}\text { Campomanesia } \\
\text { (Cambess) O. Berg, }\end{array}$ & Caatinga & NR \\
\hline Myristicaceae & Virola sebifera & Brazilian cerrado & NR \\
\hline Tiliaceae & Luehea grandiflora & Atlantic forest & AM (Siqueira et al. 1998) \\
\hline Rubiaceae & $\begin{array}{l}\text { Rudgea viburnoides (Cham.) } \\
\text { Benth. }\end{array}$ & Brazilian cerrado & NR \\
\hline Sapindaceae & Cupania vernalis Cambess. & Atlantic forest, Brazilian cerrado & NR \\
\hline Rutaceae & Zanthoxylum rhoifolium & Brazilian cerrado & NR \\
\hline
\end{tabular}

1. Native Forest (NF), nature reserve about $25 \mathrm{~m}$ from São João River, presenting Atlantic forest cover (80ha). The Forest Reserve is a protected area of Atlantic forest with prominent vegetation composed by trees and shrubs having a total density of 1,029 trees per hectare reaching heights of 10-25m [19]. Dominant species are listed in Table 2. Plant vegetation had been undisturbed for 30 years. Some plant species are at risk of extinction such as Cariniana legalis. Exsiccates were deposited in Herbarium PAMG of EPAMIG;

2. The Grassland (G) has gramineous cover with Urochloa brizantha syn. Brachiaria brizantha Stapf under no-till cultivation being the dominant grass; (about $1000 \mathrm{~m}$ from São João River). The G is located in the direct neighborhood of Maize;
3. Maize (M) monocropping (Zea mays cultivar AG1051) (conventional hybrid for silage) area, 5 ha, fertilized with $400 \mathrm{~kg}$ 8:28:16 NPK and 350Kg urea; Maize were planted in late January and harvested in December each year from 2004 to 2014. Last maize cultivation was in the year 2014. The maize was manually sowed on December 2014. Assessments of soils were made after the maize harvest, between August 2015 and October 2015. Weeds and pests, when they appeared, were treated with insecticide Klorpan 480 CE (three applications); Herbicides SANSON 40 SC and DMA 806 BR (one application);

4. Sugarcane (S) (0.7ha) Saccharum officinarum variety melifera melifera 418, cultivated under undetermined compost, harvested and crushed to feed livestock. This site was only evaluated in the second sample period (Table 2).

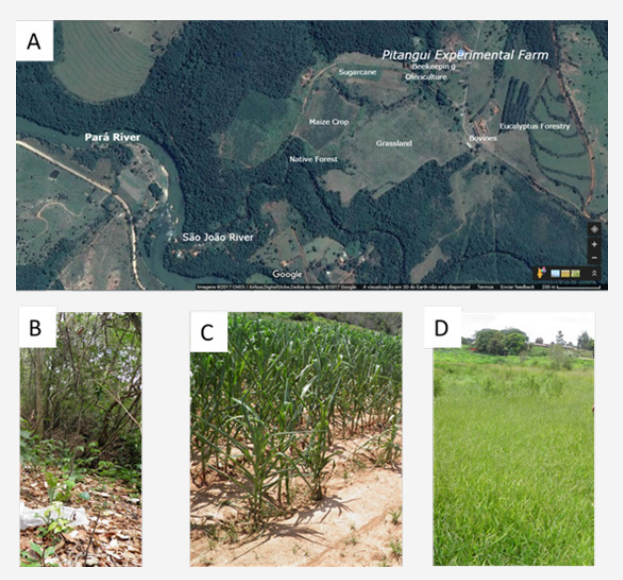

Figure 1: Location map showing experimental farm in Brazil. Plot-wise crop variety information. Google Earth image showing the locations of Native forest: Legal Reserve (Brazil's new Forest Code - Law 12651/2012) and agroecosystems in 2017 (A); Illustrative pictures of the sampling sites: native forest (B); Maize field (C) and grassland (D). 
All the sites have the same geological parent material and were classified as clayey Oxisol (Typic Acrustox) according to Soil Taxonomy [USDA 1992]. The cultivated soils are loamy (Figure 1).
The climate of the region is Tropical (Aw) with an annual average temperature of about $23{ }^{\circ} \mathrm{C}$ and predominant precipitation in summer and dry winter. This area was characterized by a total solar radiation of $7.2 \mathrm{~h}$, an average precipitation of $1337 \mathrm{~mm}$ per year.

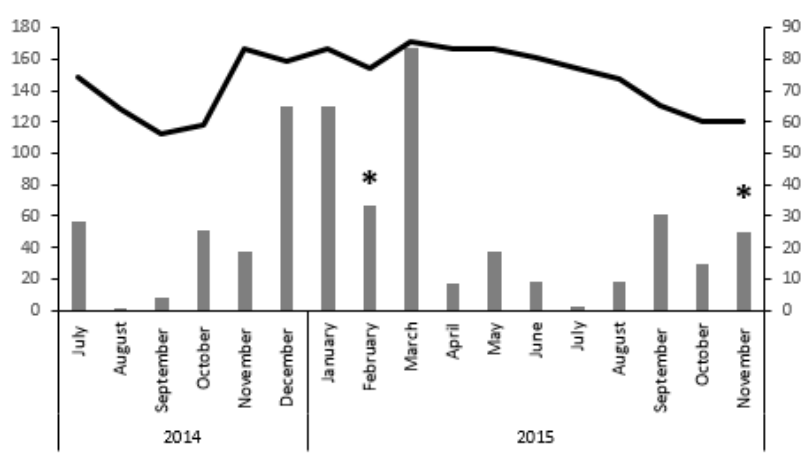

Figure 2: Mean monthly precipitation for the years 2014-2015, recorded at Meteorological station Mineração Turmalina, Jaguar Mining Inc. $\left(19^{\circ} 44^{\prime} 36^{\prime \prime} \mathrm{S}, 44^{\circ} 52^{\prime} 36^{\prime \prime} \mathrm{W}, 700 \mathrm{~m}\right)$, Minas Gerais State. *Sampling time. Lines are air humidity (\%), bars are rainfall $(\mathrm{mm})$

The study area is located in the west of Minas Gerais State, in Brazil, included in the Cerrado- Atlantic Forest region $\left(19^{\circ} 40^{\prime} \mathrm{S}\right.$ $44^{\circ} 53^{\prime} \mathrm{W}$ ), characterized by $709 \mathrm{~mm}$ of yearly precipitation concentrated in the spring-summer months from November to January (Meteorological station Mineração Turmalina, Jaguar Mining

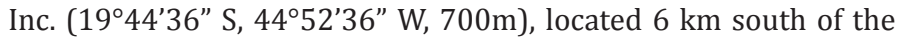
town of Pitangui. Near $84 \%$ of tropical rainfall falls during the rainy season (October to March). The months of December and January present the most intense precipitation levels. Air humidity, even in the summer, does not exceed $86 \%$ on average (Figure 2 ).

\section{Brief land-use history}

The original vegetation of the area is derived from Atlantic forest/Brazilian Cerrado ecotone, although part of the forest was deforested as early as the 1970s as revealed by interviews with local farmers. The area comprises the São João River with approximately $5 \mathrm{~m}$ width and 1 to $1.5 \mathrm{~m}$ deep. The São João basin vegetation was partially degraded and substituted by grasslands or eucalypt plantations.

The experimental farm in Pitangui has been divided into eight sectors: cultivated areas, zootechny in general and Forest reserve, dedicated to research with regional cultivars potentially important for intensive systems of production or screening programs such as rice, corn, beans, soybean, to name just a few. In the 1970s, this area was donated to the Minas Gerais State.

Typical land-use types in the area include forestry, cornfields, sugarcane plantations and grasslands. The agricultural use of the soils includes planted grassland (G); arable lands with moderate-intensity management, such as maize and sugarcane monocropping (M, S) (Table 1). The M site was established in 2004, followed by many years of annual crops. Last maize cultivation was in the year 2014 when it was manually sowed on December. The G site (in the central area, Figure 1) had been cultivated and then abandoned and left for grassland, chopped up once a year.

\section{Soil sampling and chemical characterization}

Soil samples (three replicate plots per field site; plot sizes, 5 by $20 \mathrm{~m}$ ) were obtained in February (rainy period) and November (after the dry period) 2015 at four sites.

At each of the three plots at each field site, five soil core samples were taken up to a depth of $20 \mathrm{~cm}$ with a mattock, with the exclusion of the top soil layer $(0-5 \mathrm{~cm})$, totalizing 30 samples. Samples were stored in plastic bags and transported to the laboratory of EPAMIG. Each composite sample was air dried and carefully conditioned. Each sample was stored in bags, and subsequently brought to the laboratory for analysis. Prior to further processing all visible roots and rocks were removed manually.

Table 3: Chemical properties of soils at experimental farm and adjacent Atlantic forest.

\begin{tabular}{|c|c|c|c|}
\hline & \multicolumn{3}{|c|}{ Areas } \\
\hline & Atlantic Forest & Grassland & Cultivated \\
\hline $\mathrm{pH}\left(\mathrm{H}_{2} \mathrm{O}\right)$ & 5.4 & 5.4 & 6.2 \\
\hline OC $\left(\right.$ dag kg $\left.^{-1}\right)$ & 4.5 & 2.6 & 1.4 \\
\hline $\mathrm{OM}\left(\mathrm{dag} \mathrm{kg}{ }^{-1}\right)$ & 7.7 & 4.4 & 2.4 \\
\hline $\mathrm{Ca}\left(\mathrm{cmolc} \mathrm{kg}^{-1}\right)$ & 2 & 1.5 & 4.1 \\
\hline $\operatorname{Mg}\left(\mathrm{cmolc} \mathrm{kg}^{-1}\right)$ & 0.8 & 0.9 & 2 \\
\hline $\mathrm{Al}\left(\mathrm{cmolc} \mathrm{kg}^{-1}\right)$ & 0.5 & 0.7 & 0.1 \\
\hline $\mathrm{K} \mathrm{mg} \cdot \mathrm{kg}^{-1}$ & 34 & 43 & 230 \\
\hline $\mathrm{P} \mathrm{mg} \cdot \mathrm{kg}^{-1}$ & 1.4 & 1.8 & 5.4 \\
\hline
\end{tabular}

About $500 \mathrm{~g}$ were used to determination of chemical soil parameters, according to EMBRAPA (1997). The rest of soil samples was used for AMF spore extraction and identification. Chemical properties of the soil determined by the traditional methods as described by EMBRAPA (1997). The following chemical analyses were performed: $\mathrm{pH}$ in water (1:2.5 soil/water); soil organic carbon (SOC); $\mathrm{P}, \mathrm{K}^{+}, \mathrm{Ca}^{2+}, \mathrm{Mg}^{2+}$ and $\mathrm{Al}^{3+}$ were determined according to EMBRAPA, 1997) (Table 3).

\section{AMF spore isolation and identification}

Wet sieving and sucrose density gradient centrifugation [20] extracted AMF spores occurring in the original soil samples $(50 \mathrm{~g}$ soil). The resulting supernatant was passed through the $32-\mu \mathrm{m}$ 
sieve, washed with tap water, and transferred to Petri dishes. AMF communities in each area were recorded and their diversity was estimated.

Spores and sporocarps were counted by using a dissecting microscope and mounted on slides with polyvinyl-lactic acid-glycerol and mixed 1:1 (vol/vol) with Melzer's reagent. Only the healthy-looking spores were mounted. The spores were examined under a microscope, mounted on slides and identified to the species level or attributed to a specific morphospecies. Identifications were based on current species descriptions.

The old and decaying spores with missing clear features were also counted as an approach for comparison among samples [21]. The results expressed as percentage of unviable AMF spores in the sample. Darkest black color spores or remained damaged were considered as non-viable. Unviable spore counting was done at $40 \times$ magnification (Figure 3).

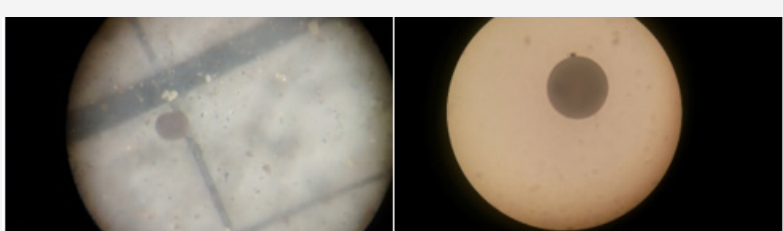

Figure 3: AMF spore isolated from soil.

\section{Greenhouse analysis}

Plant cultures (pots, $20 \times 20 \times 30 \mathrm{~cm}$ ) were produced for each site. Seeds of Sorghum BR were planted in pots filled with $3 \mathrm{Kg}$ of washed sand, vermiculite and collected soils at each field site: Sugarcane, grassland and Native forest, (1:1:1 [wt/wt]) according to Oehl et al. [10] a methodology denominated Culture Trap, were plant is the host of Fungi symbiont and promoted his growth in soil culture.

The greenhouse experiment was initiated in August 2015 and was maintained in a greenhouse in Pitangui for 3 months under day/light regimes of 12-h: 12 -h photoperiod and $28: 25{ }^{\circ} \mathrm{C}$ temperature, with a mean relative humidity of $65 \%$. Seedlings were irrigated with tap water and plant height were measured at 2 and 3 months after planting (Figure 4).

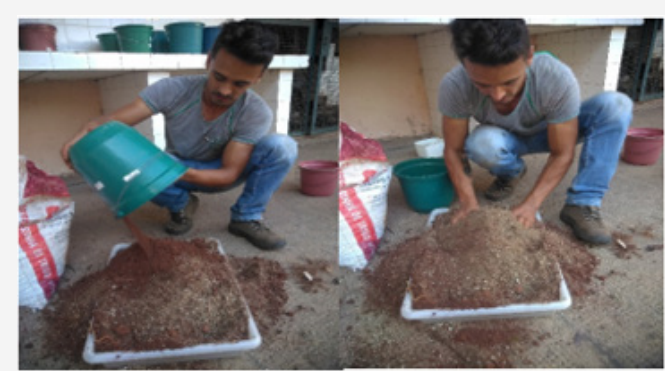

Figure 4: Student of EPAMIG ITAC preparing the Plant Culture Substrate.

\section{Statistical analysis}

The significance of differences between field sites in spore abundance, species numbers, and AMF diversity (Shannon-Weaver index) was tested by using ANOVA one-way. Homoscedasticity and data normality were tested before performing analysis of variance and test of means. Tukey post-hoc tests were used to conduct pairwise tests for significant effects. Associated means for each treatment were reported using the software Minitab 17 [9].

\section{Results}

\section{AMF occurrence}

AMF spores were counted and identified for samples taken directly from field sites. Identification of AM fungal species based on morphological features of spores in the root zone of maize, sugarcane, grassland and native forest showed 16 identifiable AMF species. One species of Glomus, one of Sclerocystis, one of Clareidoglomus, one of Ambispora, four of Acaulospora, one of Gigaspora and four of Scutellospora were detected. Four spore types could not be readily distinguished at the species level.

Table 4: AMF fungal genera found in the different sampled soils. Atlantic forest (AF), grassland $(G)$ and cultivated (M and $S)$..

\begin{tabular}{|c|c|c|c|c|c|}
\hline AMF Family & Genera & AF & G & M & S \\
\hline $\begin{array}{c}\text { Acaulospora- } \\
\text { ceae }\end{array}$ & Acaulospora & 3 & 0 & 1 & 1 \\
\hline $\begin{array}{c}\text { Ambispora- } \\
\text { ceae }\end{array}$ & Ambispora & 1 & 0 & 0 & 1 \\
\hline $\begin{array}{c}\text { Claroideoglo- } \\
\text { meraceae }\end{array}$ & $\begin{array}{c}\text { Claroideoglo- } \\
\text { mus }\end{array}$ & 1 & 0 & 1 & 0 \\
\hline $\begin{array}{c}\text { Gigaspora- } \\
\text { ceae }\end{array}$ & Gigaspora & 0 & 0 & 1 & 1 \\
\hline \multirow{2}{*}{\begin{tabular}{c} 
Glomeraceae \\
\cline { 2 - 6 }
\end{tabular}} & Funneliformes & 1 & 1 & 1 & 0 \\
\cline { 2 - 6 } & Glomus & 1 & 1 & 0 & 0 \\
\hline Pacisporaceas & Pacispora & 1 & 0 & 0 & 0 \\
\hline \multirow{2}{*}{$\begin{array}{c}\text { Scutellospora- } \\
\text { ceae }\end{array}$} & Rentiscutata & 1 & 1 & 1 & 1 \\
\cline { 2 - 6 } & Rcucocetra & 2 & 0 & 1 & 1 \\
\hline & Total genera & 13 & 4 & 6 & 5 \\
\hline
\end{tabular}

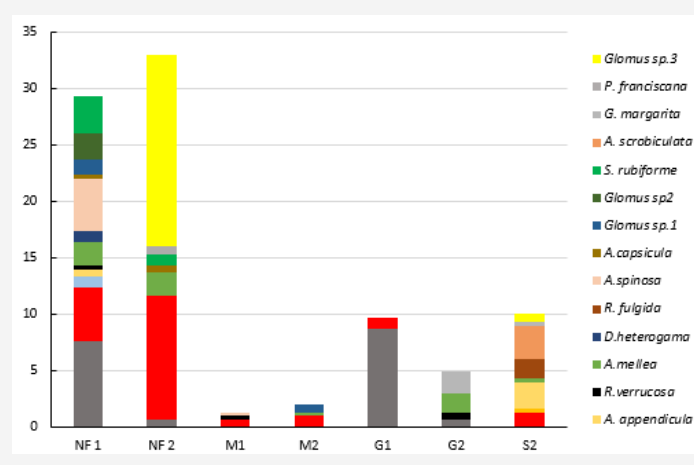

Figure 5: Abundance of AMF morphotypes detected in natural and cultivated.

In the soil samples taken from the studied systems, $16 \mathrm{AMF}$ species could be distinguished. The $10 \mathrm{AMF}$ species observed in soil sampled in the dry and rainy season consisted of seven families and ten genera (Table 4). Four species belonged to the genera Acaulospora while the genera Claroideoglomus, Gigaspora, Scutellospora, Dentiscutata and Ambispora were represented by a single species each. The species Dentiscutata heterogama, was observed in all the 
areas, in both the dry and rainy season, the last species being the most frequent (100\%). The species Sclerocystis rubiforme, Sclerocystis taiwanensis and Racocetra verrucosa were exclusive to the NF area, whereas Gigaspora margarita was observed only in the cultivated/sugarcane areas (Table 4). Glomus sp. 3 was unique to NF and A. mellea, A. scrobiculata and A. appendicula were shared between NF and Sugarcane (Figure 5).

\section{Spore numbers}

AMF spore numbers in the soil samples ranged from 1 to 23 spores per $100 \mathrm{~g}$ of soil, with an average of 8 to 12 spores, and significant differences were detected between sites (Table 5). The spore numbers in the maize field was significantly lower in the rainy period than in the NF, G and $\mathrm{S}$. The spore numbers in the NF (dry period), G, S and Maize field (dry period) were not significantly different.

Table 5: Total AMF spore numbers $(50 \mathrm{~g}$ soil) of each family in soils from Natural forest (NF), grassland $(G)$ and cultivated (M and $S)(n=3)$.

\begin{tabular}{|c|c|c|c|c|c|c|c|}
\hline \multirow{2}{*}{ AMF Family } & \multicolumn{3}{|c|}{ Rainy Period } & \multicolumn{5}{c|}{ Dry Period } \\
\cline { 2 - 8 } & NF & G & M & NF & G & M & S \\
\hline Acaulosporaceae & 6.6 & 0 & 0.3 & 2.6 & 0.6 & 0.3 & 3.3 \\
\hline Ambisporaceae & 0.3 & 0 & 0 & - & - & - & 2.3 \\
\hline $\begin{array}{c}\text { Claroideoglomera- } \\
\text { ceae }\end{array}$ & 4.6 & 1 & 0.6 & 11 & 0.6 & 1 & 1.3 \\
\hline Gigasporaceae & - & 1 & - & - & - & 0.2 & - \\
\hline Glomeraceae & 8.9 & - & - & 18.6 & - & 0.6 & 0.6 \\
\hline Pacisporaceae & - & - & - & 0.67 & 2 & - & 0 \\
\hline Scutellosporaceae & 2.9 & - & 0.3 & - & 1.6 & - & 1.9 \\
\hline
\end{tabular}

\section{Species richness and diversity}

Table 6: Richness (S), Shannon-Weaver (Hs), Simpson (D) and Evenness $(E)$ indices calculated from AMF associated with each soil at experimental farm at rainy and dry periods.

\begin{tabular}{|c|c|c|c|c|c|c|c|c|}
\hline & \multicolumn{2}{|c|}{ S } & \multicolumn{2}{c|}{ H } & \multicolumn{2}{c|}{ D } & \multicolumn{2}{c|}{ E } \\
\cline { 2 - 9 } & Rainy & Dry & Rainy & Dry & Rainy & Dry & Rainy & Dry \\
\hline $\begin{array}{c}\text { Atlan- } \\
\text { tic } \\
\text { Forest }\end{array}$ & 16 & 9 & 2.3 & 1.3 & 0.12 & 0.36 & 0.62 & 0.41 \\
\hline $\begin{array}{c}\text { Grass- } \\
\text { land }\end{array}$ & 2 & 4 & 0.33 & 1.27 & 0.81 & 0.3 & 0.69 & 0.89 \\
\hline Maize & 3 & 3 & 1.04 & 1.01 & 0.37 & 0.38 & 0.94 & 0.91 \\
\hline $\begin{array}{c}\text { Sugar- } \\
\text { cane }\end{array}$ & $\mathrm{NE}$ & 7 & $\mathrm{NE}$ & 1.66 & $\mathrm{NE}$ & 0.22 & $\mathrm{NE}$ & 0.75 \\
\hline
\end{tabular}

Mean values $n=3$.

In both seasons, the values of total species richness (S) and the Shannon diversity index were different among the areas (Table 6), indicating different composition of AMF communities, ranging from 0.33 to 2.12 . In the dry season, the AMF community had greater similarity between sugarcane and native forest areas, while in the rainy season, the AMF community of the NF had greater richness.

The species numbers in the grassland was slightly, but significantly lower in the rainy than in the dry period despite the fact that the similar precipitation had been registered, but more humidity was detected in the rainy period.
The species richness in the maize fields was slightly, but significantly lower in the both sampling periods. This analysis indicated that the different AMF communities with plant cover of grassland/ cultivated samples did not associate with the native fertile soil (Table 7).

Table 7: Distribution of AMF species associated with each soil at experimental farm, Minas Gerais state, Brazil (+, presence; -, absence) at both sampling periods.

\begin{tabular}{|c|c|c|c|c|}
\hline \multirow{2}{*}{ AMF Species } & \multirow{2}{*}{$\begin{array}{l}\text { Atlantic } \\
\text { Forest }\end{array}$} & \multirow{2}{*}{$\begin{array}{l}\text { Grass- } \\
\text { land }\end{array}$} & \multicolumn{2}{|c|}{ Cultivated } \\
\hline & & & Maize & Sugarcane \\
\hline \multicolumn{5}{|c|}{ Acaulosporaceae } \\
\hline Acaulospora Capsicula & + & - & - & - \\
\hline A. Mellea & + & - & - & + \\
\hline A. Scrobiculata & - & - & - & + \\
\hline A. Spinosa & + & - & + & - \\
\hline Acaulospora sp.1 & + & - & - & - \\
\hline \multicolumn{5}{|c|}{ Ambisporaceae } \\
\hline Ambispora Appendicula & + & - & - & + \\
\hline \multicolumn{5}{|c|}{ Claroideoglomeraceae } \\
\hline $\begin{array}{l}\text { Claroideoglomus Etuni- } \\
\text { catum }\end{array}$ & + & + & + & + \\
\hline \multicolumn{5}{|c|}{ Gigasporaceae } \\
\hline Gigaspora Margarita & - & - & - & + \\
\hline \multicolumn{5}{|c|}{ Scutellosporaceae } \\
\hline Scutellospora Calospora & + & - & - & + \\
\hline Racocetra Verrucosa & + & - & - & - \\
\hline Racocetra Fulgida & + & + & - & - \\
\hline $\begin{array}{l}\text { Dentiscutata Hetero- } \\
\text { gama }\end{array}$ & + & - & + & - \\
\hline \multicolumn{5}{|c|}{ Glomeraceae } \\
\hline Funneliformes Geosporus & + & + & - & - \\
\hline Glomus sp. 1 & + & + & - & - \\
\hline Glomus sp. 2 & + & + & - & - \\
\hline Glomus sp. 3 & + & & - & + \\
\hline Sclerocystis Rubiforme & + & - & - & - \\
\hline Sclerocystis Taiwanensis & + & - & - & - \\
\hline Species Richness & 16 & 5 & 3 & 7 \\
\hline
\end{tabular}

Data obtained at $0-20 \mathrm{~cm}$ soil depth. bMaximal AMF richness found in each sample $(n=6)$.

Table 8: Mean number of unviable AMF spores and macro-charcoal fragments in soils from Atlantic forest (AF), grassland (G) and cultivated with sugarcane $(\mathrm{S})$ or maize $(\mathrm{M})$

\begin{tabular}{|c|c|c|}
\hline Site & Unviable Spores & Macroscopic Charcoal \\
\hline AF & $4.66 \pm 3.7 \mathrm{~b}$ & $28.33 \pm 13.05 \mathrm{ab}$ \\
\hline G & $27.66 \pm 9.6 \mathrm{ab}$ & $19.66 \pm 3.21 \mathrm{ab}$ \\
\hline M & $62.33 \pm 24.7 \mathrm{a}$ & $8.33 \pm 5.03 \mathrm{bc}$ \\
\hline S & $13.66 \pm 8.9 \mathrm{ab}$ & $47 \pm 15.71 \mathrm{a}$ \\
\hline
\end{tabular}

$\dagger$ Average for three replicates plots $(25 \mathrm{~g}$ soil) of field site in November 2015. Data are means \pm SE. Mean values with the same uppercase letter in the treatment do not differ among themselves in the ANOVA Tukey test $(p<0.05)$. 
The number of viable AMF spores in the soil samples, which was evaluated in the dry period, ranged from $\sim 5$ to 62 spores per $100 \mathrm{~g}$ of soil, with an average of $36.2 \pm 15.5$ spores, but no significant differences were detected between sites (Table 8).

\section{Greenhouse experiment}

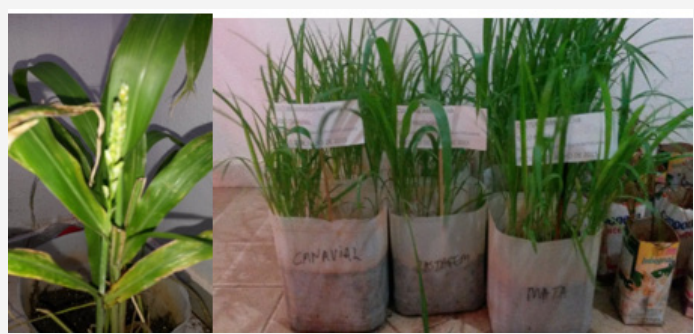

Figure 6: Abundance of AMF morphotypes detected in natural and cultivated.

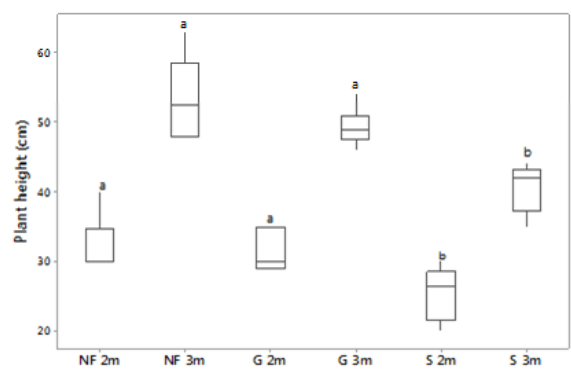

Mean values with the same letter among the inoculum sites do not differ among themselves in the ANOVA Tukey test $(p<0.05)$.

Figure 7: Sorghum height Growth in greenhouse experiment at 2 and 3 months after cultivation with inoculum from NF, G and S. Experiment realized at 2015.

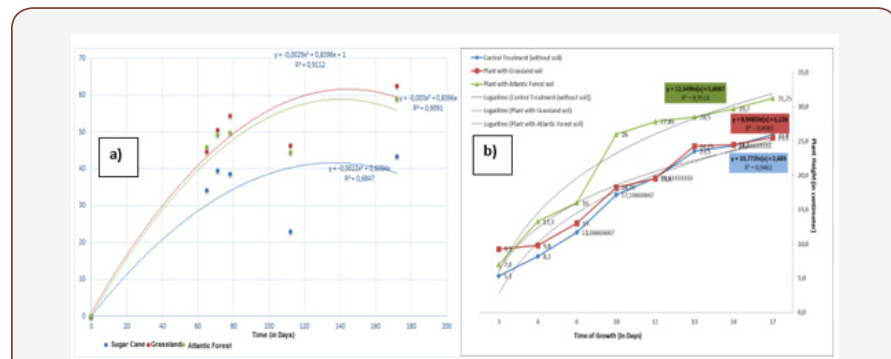

Figure 8: Sorghum height Growth under greenhouse conditions after 2 and 3 months after cultivation with inoculum from NF, G and S. a) Experiment realized at year 2015 and b) Experiment realized at 2018 .

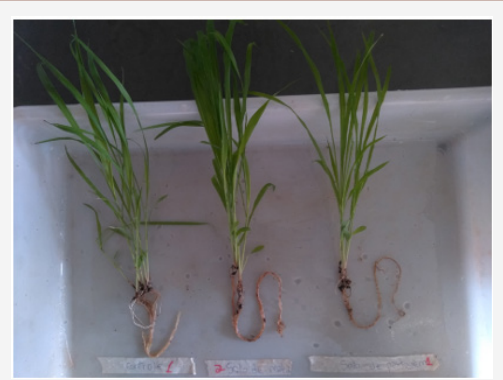

Figure 9: Sorghum Plant cultivated under Tap Culture with NF Atlantic Native Forest Soil, G - Grassland Brachiaria sp soil and Control Treatment - Trap Culture without soil only with Sand and Vermiculite (1:1). Experiment realized at 2018.
The results of the greenhouse experiment showed higher growth of Sorghum inoculated with soil from the native forest and from the grassland sites (Figure 4) than with soil from the cultivated area. Sorghum height in greenhouse experiment at 2 and 3 months after cultivation was significantly higher by the use of inoculum from NF and G sites (Figure 6,7,8 \& 9).

\section{Discussion}

Our study provide support for the hypothesis that AMF communities are limited in their diversity by monocultures. We found that preserved ecosystem (Atlantic Forest ecotone) was more diverse than agroecosystems, not only in plant diversity but also in AMF diversity and in improved soil OC content and soil aggregation.

The cultivated soils presented high fertility, a higher $\mathrm{pH}$ value, and lower organic matter content than native forest soil, which presented moderate fertility and low $\mathrm{P}$ and $\mathrm{K}$ levels. This shows that agriculture as practiced in tropical agro-systems for Brazil, negatively affects the satisfactory nutrient levels (with excess of $\mathrm{Ca}, \mathrm{K}$, $\mathrm{P}$ and $\mathrm{Mg}$ ), increases $\mathrm{pH}$ and decrease $\mathrm{OM}$ in top soils. Consistent supplies of fertilizers and lime are required in naturally acid soils (high contents of aluminum and iron oxides, low CEC values and OM content) in Cerrado [22].

For P applications in Brazilian crop production systems, soil test P methods indicate that quantity of plant-available soil P [23] and the required fertilizer level is then inferred. However, the loss of fertilizers in agricultural runoff from soils (negative impacts of Brazilian agriculture) can be controlled via use of conservation tillage, cover crops, buffer or riparian zones [23], and conservation/ augmentation of biofertilizers/soil conditioners [24].

The proportion of aggregates $>2 \mathrm{~mm}$ in the investigated soils slightly decreases in the following order: NF and G > crop. However, microaggregates were significantly lower in forest soils than in $G$ and cropland. Similar results from Portella et al. (2012) [8] reported that macroaggregates are sensitive to changes in management practices and, from Blanco-Canqui and Lal (2004) [24] reported some variation in microaggregates. It is also known that water-stable aggregates $>0.25 \mathrm{~mm}$ together with soil OM content can significantly control erodibility [27]. Moreover, the tillage practices adopted in croplands can disrupt soil aggregates [9], increase soil compaction and disturb plant and animal populations that contribute to soil aggregation.

A higher hyphal length, root colonization by AMF and AMF (spore) species diversity is expected in native forest than cultivated sites, due to a permanent plant cover, higher soil OM content and soil humidity [27]. Thus, the higher macroaggregates content under NF in rainy period can be due to a higher hyphal growth. Soils under permanent grassland can also store higher soil OM in larger aggregates than samples under permanent maize [9].

The observed higher quantity of macroscopic charcoal in sugarcane and NF than in grassland and maize was consistent with results by Schneider et al. (2011) [28] showing unchanged charcoal chemical quality and stocks along 100 years in a tropical ecosystem in western Kenya. The notable increase of charcoal in the sugarcane 
site suggesting fire activity maybe by burning management in a previous period.

Indeed, results showed that each site correlate with distinct soil attributes. NF associated with OC, charcoal, and macroaggregates. Thus, soil chemical properties such as $\mathrm{Al}, \mathrm{Ca}, \mathrm{Mg}, \mathrm{P}$ and $\mathrm{K}$ concentrations of soil $\mathrm{C}$, and soil aggregates are the main soil factors distinguishing sites. This study evaluated the AMF communities in different sampling sites showing that spores belonging to 9 genera of Glomeromycotina were detected. The results showed that preserved ecosystem (Atlantic Forest) was more diverse than agroecosystems, wherein $\mathrm{pH}$ is higher, and higher levels of $\mathrm{Ca}, \mathrm{P}$ and $\mathrm{K}$ were detected.

In general, spore-based morphological studies demonstrated that application of fertilizers, pesticides, and fungicides results in significant loss of AMF diversity in many ecosystems [29]. We predicted that spore-based morphological studies could detect the occurrence of Gigasporaceae and Scutellosporaceae in more preserved areas (two species of Racocetra and one of Scutellospora were found). The total number of AMF species varied among the evaluated areas being higher in preserved area of Atlantic Forest (NF), observing that number of AMF spores in preserved area ranged from 9 to 47 spores in $50 \mathrm{~g}$ soil.

In both seasons, the values of total species richness (S) and the Shannon diversity index were different among the areas, indicating different composition of AMF communities. In dry season, the AMF community had greater similarity between sugarcane and forest areas, while in rainy season, the AMF community of NF had greater richness. This pattern suggests that AMF community is affected not only by the host, but also by climatic conditions, and possibly by soil conditions [30]. Azevedo et al. (2014) [31] also found a high number of AMF species (37) in a small area of sugarcane plantations. Aidar et al. (2004) [32] found that $\mathrm{H}$ (from 1.10 to 1.96) late successional preserved Atlantic forest at Alto Ribeira State Park in Sao Paulo.

The $\mathrm{S}$, where the plant protection strategy is non-burning management and compost addition, resembled more the $\mathrm{G}$ than the conventional M. The successional dynamics described here are in line with Whittaker's (1972). The species numbers in crop fields and grassland was slightly, but significantly lower in the conventional than in organic treatments despite the fact that same crop rotation had been applied. The species richness in crop fields and grassland was slightly, but significantly lower in the conventional than organic treatments despite the fact that the same crop rotation had been applied. This result was confirmed in the trap cultures.

This study agrees with Oehl et al. [10] who also found a decrease of spore abundance of AMF species not belonging to the genus Glomus in Monocultures. Many of these species appeared to prefer or even to be restricted to forest systems. This was the case for most species of Acaulospora identified from field as well as for Acaulospora sp. and Entrophospora infrequens. A previous study indicated a trend towards an increase in AMF belonging to genera Acaulospora, Scutellospora and Entrophospora under long-term reduced tillage managements [33].
Our study complements this finding, indicating that not only reduced tillage but also organic farming may increase the diversity of AMF species and genera in arable lands. Our findings indicate that some AMF species, especially Acaulospora spp., find an ecological niche in soils of organic farming systems, and that this may be connected with characteristically low level of readily available P in these soils [10]. We hypothesize that these AMF species are functionally important to natural ecosystems and low-input sustainable farming; if this is true, their loss under conventional farming would be alarming.

The reduced AM fungal diversity in annual croplands compared to grasslands corresponds with some other studies in tropical regions [10] and supports the reported inverse relationship between agricultural land use intensity and AM fungal diversity [10]. The number of spores in cultivated area was much lower. This spore distribution points to hypothesis of greater sporulation of AMF detected in more preserved areas.

Unviable AMF spore number in soil samples ranged from 5 to 62 spores per $100 \mathrm{~g}$ of soil. The average spores number agree with the proportion of viable spores, in surface soil, from 35 to $60 \%$ detected by the MTT test $[21,34]$. In the present study, the proportion of unviable spores in NF was lower but not significant than in the other sites, with a possible stable spore production and loss from spore bank.

Sporulation and dormancy are of prime importance for the long-term persistence and survival of AMF in any habitat. The AMF spore bank in soil (formation of new spores and removal from the bank by death and by germination) will determine the spore numbers in soils [10]. AMF species differ in their sporulation and germination dynamics [10]

Sorghum growth experiment at 2 and 3 months after cultivation was significantly higher by use of inoculum from NF and $G$ sites. This can be due to different propagules that can be present in NF and G such as hyphae and spores, corroborating a great bank of propagules. The finding of higher AMF diversity and plant infection potential in organic as compared to conventional treatments fits well with previous observations of a higher soil aggregate stability. AM inoculation in combination with biochar application may be applicable not only for maize production but also for Phyto stabilization of Cd-contaminated soil [35]. Dai et al. [36] AM fungal resources of soils being resilient to disturbance and that richness of AM fungi under cropland management has been maintained, despite evidence of a structural shift imposed by this type of land use. Roadsides in prairie are a good repository for conservation of AM fungal diversity.

AMF colonization of sugarcane roots in current study is within the range observed in other studies, i.e. 10 to $89 \%$ in sugarcane under different field and greenhouse conditions [37-39]. However, no-burning management resulted in higher root colonization after the first harvest, as compared to pre-harvest burning management. Possible explanations for these results are: (I) an enhanced degradation of the litter driven by the tillage, and (II) more abundant organ mineral interactions preserving SOM from degradation and 
driven by the higher root density under grassland. Lignin balance showed that lignin stocks were more efficiently preserved under ley and permanent grassland than under permanently cropped soils.

AMF spores were counted and identified for sample taken directly from field sites. Identification of AM fungal species basing on morphological features of spores in rhizosphere soil of maize, sugarcane and native and restored forest.

In both seasons, the values of total SR and the Margalef diversity index were very similar among the areas, indicating similar composition of AMF communities, ranging from 50 to $66 \%$. In the dry season, the AMF community had greater similarity between pasture and forest areas, while in the rainy season, the AMF community of the regeneration area had greater similarity to that of forest fragment. This pattern suggests that AMF community is affected not only by host, but also by climatic conditions, and possibly by soil conditions [30].

The species numbers in crop fields and grassland was slightly, but significantly lower in conventional than in organic treatments despite the fact that same crop rotation had been applied. This result was confirmed in trap cultures. In this way, the present study demonstrated the importance of symbiosis with AMF in preserved areas as potential for the establishment of AMF inoculants for species of economic interest typical of region.

The inoculum potential of soil samples from the different treatments in field trial was determined in AMF trap cultures by measuring the proportion of root length of trap plants after 2 months of culture. It was found to be highest in the decreased samples from in same order as the spore abundances observed.

The benefits of AMF to their host plants could not be explained by improved nutrition alone, since interaction with the remaining soil organisms (i.e., priming effect of mycorrhiza) also differed between inoculated AMF. Due to distinct socialization strategies between inoculated AMF and remainder soil microbes and fauna, inoculation with irregulars and especially with Scutellospora sp. did not overrule the soil's legacy from maize monocropping (and thus the negative feedbacks), while inoculation with $C$. claroideum, F. mosseae and Gigaspora sp. Did [40].

\section{Conclusion}

The soil management adopted in cultivated areas decreases the density and diversity of AMF spores in relation to adjacent natural vegetation. The present analysis of the surface profile of soils revealed that Sugarcane cultivation leads to significant accumulation of charcoal. Sugarcane showed most benefic than maize cultivation systems. The most accumulation processes occurred in reclaimed soils, which is due to input and mineralization of plant residues and soil amendments [41].

The best strategy for reclaimed the degraded cultivable soils could be to add AMF inoculum better than abandoning cropland for succession, as unviable spores and lower spore abundances are present. Thus, soil content can indicate more closely related to natural soils attributes, when soil. Soil inoculation with propagules of AMF positively influenced the plant height grown in the greenhouse.

These results demonstrated good prospects for study of functional diversity of mycorrhizae to attain greater productivity of regional agricultural systems. Stimulates more effective and ambitious conservation actions in the region to address the increasing human pressure and demand for agricultural land expected in coming decades.

We highlight the need of introduction or maintenance of AMF spore bank in soil for agronomic management practices. Recommendations are made for AM functional groups, such as to maintain preserved forest on rural farm as a source of ecosystem services, which can be the dispersal of AMF propagules and for use in the transition of conventional agriculture to organic

\section{Acknowledgement}

We thank the technical help of EPAMIG ITAC, Dr Maria Celuta Machado Viana, Embrapa Milho e Sorgo is gratefully acknowledged. We thank Estevão Pereira Lopes Neto, Estação Meteorológica Mineração Turmalina, Jaguar Mining Inc., by providing climatic data.

\section{Conflict of Interest}

No conflict of interest.

\section{References}

1. Allan E, Manning P, Alt F, Binkenstein J, Blaser S, et al. (2015) Land use intensification alters ecosystem multifunctionality via loss of biodiversity and changes to functional composition. Ecology Letters 18: 834-843.

2. Pagano MC, Covacevich F (2011) Arbuscular Mycorrhizas in Agroecosystems In: Mycorrhizal Fungi: Soil, Agriculture and Environmental Implications. In: Fulton SM ed. Nova Science Publishers New York, Pp. 35-65.

3. Ferreira DA, Carneiro MAC, Saggin Junior OJ (2012) Fungos micorrízicos arbusculares em um Latossolo Vermelho sob manejos e usos no Cerrado. Revista Brasileira de Ciência do Solo 36: 51-61.

4. Wang X, Wang X, Feng G (2015) Optimised nitrogen fertiliser management achieved higher diversity of arbuscular mycorrhiza fungi and high-yielding maize (Zea mays L.). Crop \& Pasture Science 66: 706714.

5. Campos AA B, Scotto JC, LF Costa , V Giassi , DFP Pinto, et al. (2015) Seleção de fungicidas visando à preservação de fungos micorrízicos arbusculares nativos no cultivo do feijoeiro. Revista Brasileira de Engenharia Agrícola e Ambiental 19(9): 898-902.

6. Chen YL, Zhang X, Ye JS, Han HY, Wan SQ, et al. (2014) Six-year fertilization modifies the biodiversity of arbuscular mycorrhizal fungi in a temperate steppe in Inner Mongolia. Soil Biology \& Biochemistry 69: 371-381.

7. Gomes EA, Oliveira CA, Lana UGP, Noda RW, Marriel IE, et al. (2015) Arbuscular mycorrhizal fungal communities in the roots of maize lines contrasting for Al tolerance grown in limed and non-limed Brazilian Oxisoil. J Microbiol Biotechnol 25(7): 978-987.

8. Portella CMR, Guimarães MF, Feller C, Fonseca ICB, Filho JTF, et al. (2012) Soil aggregation under different management systems. Revista Brasileira de Ciências do Solo 36(6) Viçosa Nov/Dec 2012.

9. Panettieri M, C Rumpel, MF Dignac, A Chabbi (2017) Does grassland introduction into cropping cycles affect carbon dynamics through changes of allocation of soil organic matter within aggregate fractions? Science of the Total Environment 576: 251-263.

10. Oehl F, Sieverding E, Ineichen K, Mäder P, Boller T, et al. (2003) Impact of land use intensity on the species diversity of arbuscular mycorrhizal 
fungi in agroecosystems of Central Europe. Appl Environ Microbiol 69: 2816-2824.

11. Wetzel K, Silva G, Matczinski U, Oehl F, Fester T, et al. (2014) Superior differentiation of arbuscular mycorrhizal fungal communities from till and no-till plots by morphological spore identification when compared to T-RFLP. Soil Biology \& Biochemistry 72: 88-96.

12. Öpik M, Zobel M, Cantero JJ, Davison J, Facelli JM, et al. (2013) Global sampling of plant roots expands the described molecular diversity of arbuscular mycorrhizal fungi. Mycorrhiza 23: 411-430.

13. Nogueira LR, Cristiane Figueira da Silva, Marcos Gervasio Pereira, João Henrique Gaia Gomes, Eliane Maria Ribeiro da Silva, et al. (2016) Biological Properties and Organic Matter Dynamics of Soil in Pasture and Natural Regeneration Areas in the Atlantic Forest Biome. Rev Bras Cienc Solo 40: e0150366.

14. Myers N, Mittermeier RA, Mittermeier CG, Fonseca GAB, Kent J, et al. (2000) Biodiversity hotspots for conservation priorities. Nature 403: 853-858.

15. De Lima RAF, Mori DP, Pitta G, Melito MO, Bello C, et al. (2015) How much do we know about the endangered Atlantic Forest? Reviewing nearly 70 years of information on tree community surveys. Biodivers Conserv 24: $2135-2148$.

16. Tabarelli M, Aguiar AV, Ribeiro MC, Metzger JP, Peres CA, et al. (2010) Prospects for biodiversity conservation in the Atlantic Forest: lessons from aging human-modified landscapes. Biological Conservation 143: $2328-2340$

17. Joly CA, Metzger JP Marcelo Tabarelli (2014) Experiences from the Brazilian Atlantic Forest: ecological findings and conservation initiatives. New Phytologist 204: 459-473.

18. Assis GML, Euclydes RF, Cruz DC, Valle CB (2003) Brachiaria species discrimination based on different groups of morphological traits. R Bras Zootec 32(3): 576-584.

19. Rizzini CT (1997) Tratado de fitogeografia do Brasil: Aspectos ecológicos,sociológicos e florísticos. Ambito Cultural Edic, ões Ltda Rio de Janeiro Brazil pp. 747.

20. Gerdemann JW, Nicolson TH (1963) Spores of mycorrhizal endogone species extracted from soil by wit sieving and decanting. Trans Br Mycol Soc 46: 235-244.

21. Varga S, Finozzi C, Vestberg M, Kytöviita MM (2015) Arctic arbuscular mycorrhizal spore community and viability after storage in cold conditions. Mycorrhiza 25:335-343.

22. Buol SW (2008) Soils, land, and life. Upper Saddle River: PearsonPrentice Hall, Pp. 299.

23. Shigaki F, Andrew SharpleyII, Luís Ignácio Prochnow (2006) Animalbased agriculture, phosphorus management and water quality in Brazil: options for the future Sci agric (Piracicaba, Braz.) 63(2).

24. Pagano MC, Correa EJA, Duarte NF, Yelikbayev B, O Donovan A, et al. (2017) Advances in Eco-Efficient Agriculture: The Plant-Soil Mycobiome. Agriculture 7(2): 14

25. Blanco Canqui H, Lal R (2004) Mechanisms of Carbon Sequestration in Soil Aggregates. Crit Rev Plant Sci 23: 481-504.

26. Wang G, Qingqing Fang, Yanguo Teng, Jingshan Yu (2016) Determination of the factors governing soil erodibility using hyperspectral visible and near-infrared reflectance spectroscopy. International Journal of Applied Earth Observation and Geoinformation 53: 48-63.

27. Pagano MC, Jorio A, Cançado LGOL, Takahashi JA (2013) Analysis of biochars from Amazonian dark earth: comparison with commercial and natural samples. In: International Conference BCD Bari BDC2013 Abstracts Bari: BCD 1: 132-132.

28. Schneider Maximilian PW, Johannes Lehmannb, Michael WI Schmidt (2011) Charcoal quality does not change over a century in a tropical agro-ecosystem. Soil Biology and Biochemistry 43(9): 1992-1994.

29. Bradley K, Drijber RA, Knops J (2006) Increased N availability in grassland soils modifies their microbial communities and decreases the abundance of arbuscular mycorrhizal fungi. Soil Biology \& Biochemistry 38: 1583-1595

30. Silva GA, Siqueira JO, Stürmer SL (2009) Eficiência de fungos micorrízicos arbusculares isolados de solos sob diferentes sistemas de uso na região do Alto Solimões na Amazônia. Acta Amaz 39: 477-488.

31. Azevedo LCB, Stürmer SL, Marcio Lambais MR (2014) Early changes in arbuscular mycorrhiza development in sugarcane under two harvest management systems. Brazilian Journal of Microbiology 45(3): 9951005.

32. Aidar MPM, Carrenho R, Joly CA (2004) Aspects of arbuscular mycorrhizal fungi in an atlantic forest chronosequence Parque Estadual turístico do Alto Ribeira (PETAR), SP. Biota Neotropica 4(2).

33. Jansa J, Mozafar A, Anken T, Ruh R, Sanders IR, et al. (2002) Diversity and structure of AMF communities as affected by tillage in a temperate soil. Mycorrhiza 12: 225-234

34. An ZQ Guo BZ, Hendrix JW (1998) Viability of soilborne spores of Glomalean mycorrhizal fungi. Soil Biol Biochem 30: 1133-1136.

35. Liu L, Li J, Yue F, Yan X, Wang F, et al. (2018) Effects of arbuscular mycorrhizal inoculation and biochar amendment on maize growth, cadmium uptake and soil cadmium speciation in Cd-contaminated soil. Chemosphere 194: 495-503.

36. Dai M, LD Bainard, Hamel C, Gan Y, Derek Lynch D, et al. (2013) Impact of Land Use on Arbuscular Mycorrhizal Fungal Communities in Rural Canada. Appl Environ Microbiol 79(21): 6719-6729.

37. Kelly RM, Edwards DG, Thompson JG, Magarey RC (2001) Responses of sugarcane, mayze, and soybean to phosphorus and vesicular-arbuscular mycorrhizal fungi. Aust J Agric Res 52: 731-743.

38. Reis MR, Tironi SP, Costa MD, Silva MCS, Ferreira EA, et al. (2009) Colonização micorrízica e atividade de fosfatases ácidas na rizosfera de cultivares de cana-de-açúcar após aplicação de herbicidas. Planta Daninha 27: 977-985.

39. Sivakumar N (2013) Effect of edaphic factors and seasonal variation on spore density and root colonization of arbuscular mycorrhizal fungi in sugarcane fields. Ann Microbiol 63: 151-160.

40. Dias T, Correia P, Carvalho L, Melo J, De Varennes A, et al. (2018) Arbuscular mycorrhizal fungal species differ in their capacity to overrule the soil's legacy from maize monocropping. Applied Soil Ecology 125: 177-183.

41. Pontes JS, Oehl F, CD Pereira, CT de Toledo Machado, D Coyne, et al. (2017) Diversity of arbuscular mycorrhizal fungi in the Brazilian's Cerrado and in soybean under conservation and conventional tillage. Applied Soil Ecology 117-118: 178-189. 